\title{
What of the Right to Practice a Profession?
}

\author{
Louis Henkin $\dagger$
}

Regents of the University of California v. Bakke ${ }^{1}$ is a case running over with political tensions, and it is not surprising that the result should be variously represented by meinbers of the Supreme Court. Four Justices-Brennan, White, Marshall, and Blackmun-deeined it important to highlight one constitutional doctrine as "the central meaning of today's opinions."2 Four other Justices-Stevens, Burger, Stewart, and Rehnquist-deemed it important to question that characterization. ${ }^{3}$ Observers of the Court will doubtless also differ in what they distill from the complex of opinions, and in how they add them up.

I focus on a group of issues which Bakke may have decided by necessary implication, but which the Court-and the parties, their champions, critics, and the country at large-hardly mentioned. The Bakke decision addressed admissions policies of professional schools exclusively in the light of their immediate educational goals. But admissions policies of professional schools determine not only whether applicants are admitted to the school, but also largely whether they will have the opportunity to practice their chosen profession. Thus, constitutional issues arising out of university policies on professional school admissions raise larger constitutional issues concerning societal policies about entry into the professions.

I

\section{THE COURT's Decision}

In addressing issues which the Court neglected, it is helpful to keep in mind what the Court decided. One sumunation of what the

+ Harlan Fiske Stone Professor of Constitutional Law, Columbia University. I addressed some of the issues raised here in DeFunis: An Introduction, 75 Colum. L. REv. 483 (1975).

1. 98 S. Ct. 2733 (1978).

2. Id. at 2766 (opimion of Brennan, White, Marshall, and Blackmun, J.J.).

3. Id. at 2809 n.1 (opinion of Stevens, J., with Chief Justice Burger and Stewart, Rehnquist, J.J., concurring) ("Four Members of the Court have undertaken to annonnce the legal and constitutional effect of this Court's judgment . . . . It is hardly necessary to state that only a majority can speak for the Court or determine what is the 'central meaning' of any judgment of the Court."). 
Court-i.e., a majority of five Justices ${ }^{4}$ _held might be this:

1. The Constitution does not require color-blindness; racial classifications are not per se invalid under the equal protection clause. But race is a suspeet classification, even if used to benefit a minority, and therefore its use is subject to strict judicial scrutiny. A racial classification will be uplield only to achieve a compelling state interest, and then only if a nonracial way is not available to achieve it. The Brennan group would strike down a benign racial classification if it "stigmatizes any group" or "singles out those least well represented in the pohtical process to bear the brunt of a benign progran."s Otherwise, scrutiny will be strict, but a racial classification will be upheld if "an important and articulated purpose" for a benign program is shown. ${ }^{6}$

2. A state may use racial classifications im order to eliminate or aneliorate "the disabling effects of identified, specific instances of discrimination," even "at the expense of other innocent individuals." In such cases, when there have been "judicial, legislative, or admimistrative findings of constitutional or statutory violations," a state may use racial classifications in framing "remedies for the vindication of constitutional [and statutory] entitlentent."7 Even in response to such identi-

4. A majority was made up of Justice Powell (who wrote a separate opinion) and Justices Brennan, White, Marshall, and Blackmun on some issues, and of Justice Powell and Chief Justice Burger and Justices Stevens, Stewart, and Rehnquist on other issues. Since the Brennan group accepts "racial awareness" by universities for more purposes and in more forms than does Justice Powell, Justice Powell's opmion represents a majority insofar as it is "permissive." Similarly, since four Justices (under Justice Stevens' opinion) believed that all racial classifications by universities are forbidden by Title VI of the Civil Rights Act of 1964 , there was a inajority to forbid any racial classification by a umversity which Justice Powell also thought was forbidden. (Section 601 of the Civil Rights Act of 1964 provides: "No person in the United States shall, on the ground of race, color, or national origin, be excluded from participation in, be denied the benefits of, or be subjected to discrimmation under any program or activity receiving Federal financial assistance." 42 U.S.C. \$ 2000d (1970)). Justice Stevens and those concurring in his opmion expressed no views on any coustitutional issues. Inevitably, then, the opinion of Justice Powell, although only that of a single Justice, acquired for some purposes the character of an opmion of the Court. That may cease to be so, of course, if any of the Stevens group should bow to the majority regarding Title VI, address the constitutional issues, aud adhere to the Brennan group view.

The Court did not, of course, dispose of any issues of state law. The California trial court had held that the Davis program violated not only the equal protection clause and Title VI, but also the Califomia Constitution; the California Supreme Court affirmed on the basis of the equal protection clause, without passing on the claim under Title VI or the California Constitution. The California courts may yet be called on to consider whether a program like the Harvard Collcge admissions program, which a majority of the U.S. Supreme Court accepted under the equal protection clause and Title VI, would pass under the California Constitution.

5. $98 \mathrm{~S}$. Ct. at 2785 (opinion of Brennan, J.). Justice Brennan suggests that in such cases, as in cases of imvidious discrimination, scrutimy will be " 'strict' in theory and fatal in fact." Id. (quoting Gunther, The Supreme Court, 1971 Term-Foreword: In Search of Evolving Doctrine on a Changing Court: A Model for a Newer Equal Protection, 86 HARv. L. REv. 1, 8 (1972)).

6. Justice Powell would require that the state purpose be "compelhing," but to him that means "substantial." See, e.g., 98 S. Ct. at 2756-57, 2761 (opinion of Powell, J.).

7. Id. at 2754-58 (opinion of Powell, J.). Compare id. at 2785-89 especially n.42 (opinion of Brennan, J.) (judicial, administrative, and legislative findings unnecessary). In Bakke, the Court 
fied, specific instances of discrimination, however, racial classifications cannot be instituted by the university itself," "at least in the absence of legislative inandates and legislatively determined criteria."

3. The inore general objectives of helping those "perceived as victims of 'societal discrimination" "10 or "reducing the historic deficit of traditionally disfavored minorities in the inedical schools and the medical profession," 11 are not legitimate purposes for a government to pursue by racial policies that adversely affect others.

4. A state probably may use racial classifications in soune situations in order "to promote better health care delivery to deprived citizens," but there was no evidence in Bakke that the preferential adnnissions prograin was "either needed or geared to promote that goal." 12

5. A diverse student body serves educational purposes and achieving such diversity is a constitutionally permissible goal for an institution of higher education. ${ }^{13}$ But the "genuine diversity" which

faced only the authority of the state, but the various constitutional conclusions presumably apply equally to tbe federal government. Cf. Bolling v. Sharpe, 347 U.S. 497 (1954) (dictates of Brown $v$. Board of Educ. apply to federal government as well as states).

8. This conclusion is mandated by the present form of Title VI of the Civil Rights Act of 1964. The discussion throughout this Article applies to any university, state (like Davis) or private, that is covered by Title VI because it receives federal funds. For Justice Powell the same conclusions would apply also, by virtue of the fourteenth ainendment, to a university that does not receive federal funds if it is a state university or one sufficiently imvolved with a state so that what it does constitutes "state action."

Justice Powell apparently equates state universities and private universities receiving federal funds for all purposes relevant here. But as regards issues to which Title VI does not speak, a state university is an official body and all its acts are "state action." This is not necessarily so for private universities receiving federal or other public funds. Compare note 35 infra.

9. $98 \mathrm{~S}$. Ct. at 2758-59 (opinion of Powell, J.). Referring to the Davis medical school, Justice Powell noted: "Its broad mission is education, not the formulation of any legislative policy or the adjudication of particular claims of illegality . . . . [I]solated segments of our vast governmental structures are not competent to make those decisions, at least in the absence of legislative mandates and legislatively determined criteria."

10. Id. at 2759 .

11. Id. at 2757 (quoting from Brief for Petitioners at 32).

12. Id. at 2759. The California Supreme Court had found that integrating the medical profession and increasing the numbers of doctors willing to serve minority groups were compelling state interests but that there were "more precise and rehable ways to identify apphcants who are genuinely interested in the medical problems of minorities than by race." Id. (quoting 18 Cal. $3 d$ 34, 56, 553 P.2d 1152, 1167, 132 Cal. Rptr. 680, 695).

Justice Powell did not discuss whether a university could pursue such "societal" purposes (as distinguished from educational purposes, see text accoinpanying notes 16-17 infra) on its own authority, "in the absence of legislative mandates and legislatively determined criteria." Compare text accoinpanying notes 7-9 supra. But if a state adopted a program to promote better liealth care or other professioual services to minority groups, it could probably delegate to professional schools authority to develop adinissions and other educational policies, even race-conscious ones, "needed or geared to promote that goal." $98 \mathrm{~S}$. Ct. at 2759. See text accompanying notes 37-38 infra.

13. $98 \mathrm{~S}$. Ct. at 2760-61 (opinion of Powell, J.). In Justice Powell's view, the only purposes which a university may pursue by "race-conscious" methods are educational purposes, which are 
universities may constitutionally pursue cannot be achieved by admissions based on race alone. Other individual factors must be considered. ${ }^{14}$ A state therefore may not use a racial "quota,"15 but it may "take race into account" together with other factors in individual cases. The Harvard College admissions program, as described by Justice Powell, does that and is therefore permissible; the Davis medical school program used a numerical quota and is not permissible.

II

\section{The Right of Access to A Profession}

Thus, the Court judges admissions pohicy wholly as an element of educational policy, and views the right of a university to determine whom to admit as an essential aspect of academic freedom. ${ }^{16}$ In Bakke, "tlie permissive majority"-Justices Powell and the Brennan group-was able to agree only on "diversity in education" as a legitimate purpose for "taking race into account," because for Justice Powell "achieving a diverse student body is clearly a constitutionally permissible goal for an institution of higher education."17

I think the Court overlooked a significant constitutional and social dimension in treating admissions policy only as an element of university educational policy. "[D]iversity of education" concerns almost exclusively the educational process within the university itself; it is peripheral to the social interests which professional education is designed to serve. The purposes which Justice Powell rejected as impermissible grounds for "affirmative action" by a univer-

entrusted and delegated to universities by the state. A university cannot choose to pursue larger societal objectives on its own. See note 12 supra.

14. $98 \mathrm{~S}$. Ct. at 2761-63 (opinion of Powell, J.). Although the right of a university to decide whoin to adinit is an essential aspect of academic freedom, see text accompanying note 16 infra, apparently Justice Powell considers the difference between the kinds of "diversity" achievcd by the two different methods to be a proper subject of judicial review, presumably because the use of race subjects both methods to strict scrutiny and requires a program "precisely tailored" to a compelling state interest. $98 \mathrm{~S}$. Ct. at 2753 (opinion of Powell, J.).

15. Id. at 2761. Earlier in his opinion, in a separate and apparently independent section, Justice Powell states:

If petitioner's purpose is to assure within its student body some specified percentage of a particular group inerely because of its race or ethnic origin, such preferential purpose must be rejected not as insubstantial but as facially invalid. Preferring members of any one group for no reason other than race or ethnic origin is discrimination for its own sake. This the Constitution forbids.

Id. at 2757. Since no such policy can be really "for its own sake," but must have some purpose, that seems to suggest that a "quota" is invalid per se even it it serves some compelling interest. Or perhaps Justice Powell could conceive of no coinpelling state purpose that required such racial proportionality.

16. Id. at 2760-61. One might ask whether a state university (as distinguished from individual members of the faculty or students) lias "academic freedom." Does a state university, an agency of the state, have rights as a "person" against the state under the fourteenth amendment?

17. See note 13 supra. 
sity-increasing the number of minority doctors, promoting better health care for deprived citizens, and even some kind of compensation to minority groups for past societal wrongs-at least had the virtue of seeing professional school education in its wider societal context. Diversity in education takes no account of the social implications of admission to or exclusion from professional school.

For professional schools, the constitutionality of policies aimed at such diversity calmot be determined without regard to their implication for individual rights of access to a profession. Bakke involved admission to a state inedical school. In DeFunis $v$. Odegaard, ${ }^{18}$ an affirmative action admissions program at a state law school had been challenged on similar grounds. Today, virtually the only way into the medical or legal professions is through professional school. Denial of admission to professional school is, therefore, effectively denial of access to a profession.

What restrictions may a state constitutionally place on entry to a profession? The Court has strongly suggested that freedom of choice of a vocation is an important individual right protected from unreasonable state interference by the due process clause of the fourteenth amendinent. In Allgeyer v. Louisiana the Court said: "The liberty mentioned [in the due process clause] . . . is deeined to embrace the right of the citizen . . . to live and work where he will; to earn his livelihood by any lawful calling; to pursue any livelihood or avocation . . . ."19 Ad-

18. 416 U.S. 312 (1974).

19. 165 U.S. 578, 589 (1897). See Greene v. McElroy, 360 U.S. 474, 492, 507 (1959). Since the Supreine Court began to apply a "rational basis" test under the due process clause as regards economic regulation, see, e.g., Ferguson v. Skrupa, 372 U.S. 726 (1963); West Coast Hotel Co. v. Parrish, 300 U.S. 379 (1937); Nebbia v. New York, 291 U.S. 502 (1934), the Court has had no occasion to consider whether the freedom to choose one's work is a substantial constitutional right. But the broad conception of "liberty" articulated in Allgeyer did not die when the Court abandoned it as a basis for invalidating regulation of industrial relations and other economic regulation. See Pierce v. Society of Sisters, 268 U.S. 510 (1925); Meyer v. Nebraska, 262 U.S. 390 (1923), both cited with approval recently in the "new privacy cases," Roe v. Wade, 410 U.S. 113 (1973). See note 23 infra. See also Aptheker v. Secretary of State, 378 U.S. 500 (1964) (right to travel is liberty protected by substantive due process).

Although later the Court referred to inembership in the bar as "a privilege available only to those possessing the requisite qualifications," In re Anastaplo, 366 U.S. 82, 90 (1961), I do not believe the Court was reducing the practice of law from a right to a privilege, a distinction which has long lost its erstwhile constitutional significance. See generally Van Alstyne, The Demise of the Right-Privilege Distinction in Constitutional Law, 81 HARv. L. REv. 1439 (1968). The "Bar Adinission Cases" that reached the Supreme Court in 1961 and 1971 do not imply otherwise. They dealt with the permissibility of denying admission on grounds relating to qualification for practice which implicated the first amendment. Law Student Civil Rights Research Council, Inc. v. Wadınond, 401 U.S. 154 (1971); In re Stoler, 401 U.S. 23 (1971); Baird v. State Bar, 401 U.S. 1 (1971); In re Anastaplo, 366 U.S. 82 (1961); Konigsberg v. State Bar, 353 U.S. 252 (1957). Indeed, in Baird, the plurality opinion of Justice Black said: "The practice of law is not a matter of grace, but of right for one who is qualified by his learning and his moral character." 401 U.S. at 8. See also Schware v. Board of Bar Examiners, 353 U.S. 232, 238-39 n.5 (1957) (It is "sufficient to say that a person cannot be prevented from practicing except for valid reasons. Certainly the practice 
missions policies of state professional schools, therefore, implicate substantive due process as well as, and perliaps more fundamentally than, they face the requirements of equal protection.

Constitutional issues apart, professional school admissions must be seen as integral and secondary to state pohicy on access to the professions. When a state provides only a limited number of places in its professional scliools and insists also that there is no other way into the profession than through professional school, the state is limiting the number of people admitted into the profession. ${ }^{20}$ In effect, the requirements for admission to the school are requirements for access to the profession. Because of the important role which the professions play in contemporary society and because the rights of individuals are at stake, policies underlying admissions to professional schools should not be made by academic officials concentrating on educational concerns alone. Policy should be made by representative bodies attending to wider societal considerations. ${ }^{21}$ The issue then becomes what goals these policymakers legitimately can pursue and how they may structure their programs to pursue them.

\section{Permissible Restrictions on Access to the Professions}

What limits may a state impose on entry into the professions? How do these limits relate to admissions to public professional schools?

If access to a profession is a substantial individual right, ${ }^{22}$ state restrictions on access are constitutional under the due process clause

of law is not a matter of the State's grace.") That lawyers have sometimes been treated as "officers of the court," Ex parte Garland, 7 I U.S. (4 Wall.) 333, 378 (1868), is not here relevant; in any case, that often exaggerated notion does not apply to doctors and members of most other professions.

20. Professional schools apart, how much public education should be supplied generally and who should have it are societal policies not exclusively for educational institutions to determme. See text accompanying note $30 \mathrm{infra}$. Under the United States Constitution, a state presumably need not provide any public education at all. $C$. San Antonio Independent School Dist. v. Rodriguez, 411 U.S. 1 (1973) (education is not a fundamental right for equal protection purposes); Griffin v. County School Bd., 377 U.S. 218 (1964) (county may not close schools to avoid desegregation order). At least at the college level, a state can presumably offer education to a limited number only, and need not provide seats for all who can qualify. While admission to undergraduate school is itself a prerequisite to eventual access to a profession, denial at that stage is not a direct and immediate deprivation of the right to choose a profession.

It is true that in general states do not coordmate their respective admissions policies and do not directly control admission to private professional schools; therefore there is not an exact fit between the admissions requirements for state professional school and for the profession. But to the extent that, in the aggregate, state professional schools provide a domimant share of the places in professional schools generally, state admissions policies do indeed largely shape the requirements for access to the profession.

21. See opinion of Justice Powell, discussed in notes 9, 12, 13 supra.

22. See note 19 supra, note 23 infra. 
only if they further a legitimate public interest. If the right to choose one's profession were held to be among the "personal rights that can be deemed "fundamental," the state interest would have to be "compelling." 23

Clearly, a state can limit admission to a profession to those who can prove their competence to practice, as by bar examinations or "Medical Boards."24 For the same reason, a state probably can require also that an apphicant have pursued a prescribed course of studies in an accredited institution. ${ }^{25}$ On the other hand, states have not commonly placed limits on the number of qualified apphicants to be admitted to various professions. (Whatever limits are imposed on the number of students in professional schools in the state, states generally also admit qualified graduates from out of state without apparent limit.) Some limitations on total numbers of practitioners might be permissible as serving an important public purpose-for exaunple, controlling competition among professional inembers that would affect the quality of their services to the commumity.

If a state may exclude the incompetent and limit the number of competent apphicants admitted to practice, it may presumably do so at an earher stage, by limitimg the numbers ${ }^{26}$ and screening the quahty ${ }^{27}$

23. Roe v. Wade, 410 U.S. 113,155 (1973). One could argue that the right to choose how to earn one's hvelihood is a fundamental right, part of the new right of privacy. The broad Allgeyer language is reiterated in Meyer v. Nebraska, 262 U.S. 390, 399 (1923), one of the pillars of the modern right of privacy. Cf. Massachusetts Bd. of Retirement v. Murgia, 427 U.S. 307, 320-21 (1976) (Marshall, J., dissenting) (right to work an important "interest" protected by due process). See generally Roe v. Wade, 410 U.S. 113 (1973); Griswold v. Connecticut, 381 U.S. 479 (1965); Henkin, Privacy and Autonomy, 74 Colum. L. Rev. 1410 (1974).

24. See the discussion of the Bar Admission cases in note 19 supra. "Competeuce" may include "character" and related quahties, at least for some professions. See note 27 infra.

25. States have not commonly imposed other requirements. Citizenship is no longer a permissible requirement even for the practice of law. In re Griffiths, 413 U.S. 717 (1973). Residence requirements have not been strongly challenged.

26. Limitimg the number of places in public professional schools seems to reflect, perhaps principally, fiscal and other considerations of educational "feasibility," rather than a pubhic need to limit the numbers adinitted to the profession. Is an applicant, theu, perhaps entitled to ask that the state provide access to the profession by alternative routes for those who could prove their competence?

27. An applicant rejected as "insufficiently qualifled" unight challenge the appropriateness of the standards for admission to the school as a measurement of competence to practice the profession. He might also question the appropriateness of judging competence to practice before rather than after he has had professional education. Denying a person who may have the ability to learn a profession entry into a professional school is not so clearly justiflable as denying entry into the profession to one who has received training but cannot prove competence.

In law school, for example, there is apparently a respectable correlation between the standard measures which form the basis of a judgment of "competence"-college performance, the Law School Admission Test-and performance in professional school, especially in the first year. Few claim a high correlation, however, between these accepted ineasures and competence to practice the profession. But the state, through faculty admissions committees, is entitled to do as well as it can, and in the absence of obviously more aceurate ineasures, it is difficult to fault those professional school admissions standards on constitutional grounds. Nevertheless, the uncertainty of 
of those admitted to its state professional schools. Whether a state can constitutionally limit the number of students admitted to private professional schools in the state raises additional questions not considered here. States do in fact regulate the establishment of new private law schools and medical schools, and to some extent also regulate the size of existing schools. Indeed, this may reflect an impressionistic view of how many lawyers or doctors are needed in the state or in the nation. ${ }^{28}$

Assuming that a state may constitutionally limit the number of places provided in professional schools in the state, how can a state constitutionally select among qualified, potentially "competent" qualified candidates? ${ }^{29}$ Since the schools are effectively conduits into the profession, criteria, although admimistered by faculties, ought not to be only, or primarily, "educational," but should reflect societal policies on professional needs. ${ }^{30}$

Professional schools generally have assumed, and the Court in Bakke has tacitly accepted the assumption, that the principal and

university admissions standards as measures of competence to practice the profession may reinforce the claims of those denied admission to have access to the profession by an alternate route, with the opportunity to prove their competence later by other means, principally the bar examination.

28. Justice Blackmun noted in his opimion in Bakke the fact of limited access, but did not relate it to constitutional issues; perhaps he did not think there were any worth discussing.

The number of qualified, indeed highly qualified, applicants for admission to existing medical schools in the United States far exceeds the number of places available. Wholly apart from racial and ethuric considerations, therefore, the selection process inevitably results in the denial of admission to many qualified persons, indeed, to far more than the number of those who are granted admission. Obviously, it is a denial to the deserving. ... .

One theoretical solution to the need for more mimority members in higher education would be to enlarge our graduate schools. . . . Unfortunately, this is neither feasible nor realistic. ... And the need for nore professional graduates, im the strict numerical sense, perhaps has not been demonstrated at all.

$98 \mathrm{~S}$. Ct. at 2806 (opimion of Blackmun, J.).

The extent to which a state is entitled to rely on private and out-of-state institutions should also be explored. See Missouri ex rel. Gaines v. Canada, 305 U.S. 337 (1938).

29. The constitutional limits on the selection criteria would themselves be limitcd by due account for academic freedon. See text accompanying and note 16 supra. I assume that a state may employ such "neutral" grounds as priority of application, and perhaps even random selcction, to choose among candidates who meet the inimimum standards of competence.

30. Justice Blackmun states that "[p]rograms of admission to institutions of higher learning are basically a responsibihty for acadeinicians and for administrators and the specialists thcy employ." $98 \mathrm{~S}$. Ct. at 2807 (opinion of Blackmun, J.). But should the policies that guide them also be theirs to formulate, especially simce they are public institutions guarding the entry gate to the professions? Justice Powell apparently recognizes the himited authority and legitimate concerns of universities, as distinguished from legislatures, hence his reliance wholly on a purpose which is educational (diversity of student body), not societal. See notes 9, 13 supra. But surely the legislature can delegate to universities the implementation of state policy by and in the admissions process. See note 12 supra.

Some professional schools, including some leading law schools, see themselves not only as professional schools but as graduate schools in an academic, intellectual discipline. A state system of professional schools may be entitled to take that into account, but with due attention to the fact that they are primarily the state's narrow conduit into a profession. 
proper criterion is comparative "merit." Among the "competent" the state may-some say must-give preference to the "more competent." But since regulation of access to a profession is justified by the need to assure that only competent people practice the profession, is it obvious that it is permissible for the state to exclude from school (and the profession) the "merely competent" in favor of the "more competent?"31 And how far may the state apply such comparisons: may a state, consistently with due process of law, decide to admit to its professional schools (and to the professions) only those with " $A$ " averages froin prestigious colleges and a perfect score on a professional aptitude test? At some point, surely, higher levels of "competence" become irrelevant if not imaginary, not "job related,"32 and would exclude from the profession highly competent practitioners; they are therefore, perhaps, not a constitutionally permissible basis for preference between two competent aspirants to a profession. This raises a question as to whether a state may apply such standards from other motives, perhaps in order to establish an "elite," "national" professional school, or to contribute to higher professional standards.

Assuming that comparative competence is a permissible basis for selection, perhaps even the required basis for selection, which-if any-deviations from that order of merit are permissible? In Bakke, a majority of the Court accepts, without much discussion, that a public university may use a "far broader array of qualifications and characteristics" (than competence) in order to achieve a diverse student body, and for Justice Powell diversity is even a "compelling state interest."33 Justice Blackmun notes that "institutions of higher learning, albeit more on the undergraduate than the graduate level, have given conceded preferences up to a point to those possessed of athletic skills, to the children of alumni, to the affluent who may bestow their largess on the institutions, and to those having connections with celebrities, the fainous and the powerful." 34 Such deviations from order of merit are not constitutionally forbidden to private institutions. ${ }^{35}$ Whether such

31. The difficulty is accentuated by the fact that prognostications of professional competeucy are highly speculative. See note 27 supra.

32. See Griggs v. Duke Power Co., 401 U.S. 424 (1971).

33. $98 \mathrm{~S}$. Ct. at 2761 (opinion of Powell, J.).

34. Id. at 2807 (opinion of Blackmun, $\mathrm{J}$.).

35. Some private institutions might be subject to constitutional limitations if there is sufficient state involvement im the institutions to satisfy the state action requirement. See note 8 supra. If they are not sufficiently "public," they are probably permitted to be capricious, or even invidious in their admissions policies and practices. If they receive federal funds, they would be subject to Title VI and would be forbidden from admitting applicants on the basis of race. Nonetheless, they would not necessarily be rendered public institutions which are forbidden by the due process clause from practicing other forms of invidious selection as well. Consider Justice Powell's comment:

So long as the university proceeds on an imdividualized, case-by-case basis, there is no warrant for judicial imterference in the academic process. If an applicant can establish 
deviations are permitted to public colleges has not been autloritatively determined. Some public undergraduate colleges may be able to justify them, at least where the state provides other opportunities of undergraduate education for all competent applicants. But a state professional school that mdulges $\mathrm{m}$ such deviations frustrates the right of meritorious applicants to pursue the profession of their choice. Does not the state liave to justify sucli deviations from order of merit by some important, perliaps compelling, state interest? ${ }^{36}$

The Bakke Court and the national debate that has swirled about the case liave not seen the whole problem. The Court, therefore, accepted "comparative inerit" as the principal criterion for admission to state professional scliools, and "educational diversity" as tlie principal reason for deviating from that criterion. Attention to the long-term interests of the individual applicant and to the larger concerns of the society would liave refocused issues and broadened the Court's perspective. Sucl attention in the future would lead to more rational state policies that affect access to the professions and to admissions policies that pronote and support those policies.

\section{IV}

\section{InCREASING Minority ACCess to the Professions}

Consideration of the permissible uses of race in admissions to professional scliools requires that we sort out the character of a state's control over adımission to the professions and wliat the Constitution requires of the state in its exercise of that control. Within constitutional limits, states ouglit to consider the professions in broad societal terms, and fit the qualifications for admission and the size of professional scliools to that conception. Guided by those state policies and the authority delegated to universities to furtlier them, admissions policies for professional schools sliould be tailored, articulated, and carefully administered to achieve tliese goals. ${ }^{37}$ If a state developed a clear policy on admissions to the professions, the Court might well accept a pro-

that the institution does not adhere to a policy of individual comparisons . . . the presumption of legality might be overcome, creatimg the necessity of proving legitimate educational purpose.

98 S. Ct. at 2763 n.53 (opinion of Powell, J.).

36. Justice Powell recognizes some differences between graduate and undergraduate adinissions but does not appear to consider them significant. Id. at 2761 \& n.49.

"Although a university must have wide discretion in making the sensitive judgments as to who should be admitted, constitutional limitations protecting individual rights inay not be disregarded." Id. at 2761. What Justice Powell said in regard to individual rights to equal protection applies equally to individual rights to substantive due process, here to the right to practice a profession. Where else do we leave such wide discretion in matters affecting an inportant constitutional right in the hands of anonymous state officials, exercising unknown standards, without scrutiny?

37. See note 30 supra. 
gram for increasing the number of minority members and university admissions policies "precisely tailored" to implement that program. ${ }^{38}$

The constitutional issues that concern me antecede issucs of "taking race into account" in admissions to professional schools; but they are also highly relevant to affirmative action programs. For the raceconscious admissions policies that have divided the Court and our society can, at best, have only modest success im achieving their authentic societal goal-to increase the number of disadvantaged minority members in the professions. ${ }^{39}$ Implied in my analysis of Bakke is a very different, and perhaps more promising, avenue to that end. The states, under pressure and scrutiny from the courts, ought to reexamine all state policies which lead to the exclusion of minorities from the profession. These include: 1) inadequate attention to societal-professional needs in deciding how many individuals should be educated in the professional schools in the state, as well as the the content and duration of the education that should be provided; 2) insistence by the state on a kind of professional education which can only be made available to few, witlout considering possible alternate routes into the profession; 3) imsistence by some state professional schools on being national, elite schools, when the state does not also provide othcr, less elite schools for resident students; 4) underdeveloped notions of professional competence; and 5) insistence on preference for "comparative merit" in state schools, beyond the level at which it has much to do with potential competence to practice a profession. Reexamination of these obstacles to an individual's constitutional right to entcr a profession which he is potentially competent to practice might do more than university affirmative action programs to bring the disadvantaged into the professions.

38. Compare notes $5,6,12$ with their accompanying text supra.

39. In the legal profession, they seem to have increased the numbers of minority members graduated from "prestigious" law schools, but not dramatically increased the numbers of minority members in the profession. 
